\title{
A NEW MARINE DINOFLAGELLATE: EXUVIAELLA MARIAE-LEBOURIAE N.SP.
}

\author{
By Mary Parke and Dorothy Ballantine
}

The Plymouth Laboratory

(Text-figs. I-I8)

Exuviaella mariae-lebouriae n.sp., Parke \& Ballantine

Exuviaella apora Schiller pro parte, in Lebour, 1925, (non E. apora Schiller, 1918). Exuviaella apora Schiller, in Martin, 1929.

\section{Diagnosis}

Cell ovoid to almost sphaeroidal in face view of right or left valve, lenticular to almost sphaeroidal in view showing junction of valves, in both views flagellar pole flattened, length (I0) I4-I 7 (22), breadth (9) II I-I 5 (20), thickness (5) 6-8 (I8) $\mu$. Two valves of cellulose, each with a striated band at margin, band wider in larger cells, striations about $0.5 \mu$ apart, remainder of valve surface with poroids, apparently in rows, $0.25 \mu$ apart, poroids $0.2-0.25 \mu$ diameter; right valve with shallow indentation, about $2 \mu$ wide, at flagellar pole, usually lying to left of centre line; left valve with small projecting flange, about $2 \mu$ wide, bearing flagellar pores and fitting into and over indentation on right valve; the two flagellar pores of unequal size, in apical view larger nearly triangular, smaller circular, in left valve view smaller pore to left of larger. Two flagella, one emerging from larger pore undulating parallel to, and round, flagellar pole, $2 \cdot 5-3$ times body length; the other, I.25-I. 5 times body length, emerging from smaller pore. One obvious, usually ovoid, pusule, $I \cdot 5-4 \mu$ in length, in left valve view close to surface on the right side near flagellar pole, opening to exterior by canal to larger flagellar pore; second smaller pusule sometimes present but connexion to exterior not visible. Nucleus posterior, broadly ellipsoidal in valve view. Chromatophores golden-brown, usually two in smaller cells, large, parietal, saucer-shaped with deeply lobed margins, with a single large pyrenoid on inner face of each lying in anterior part of body; in larger cells chromatophores smaller and more numerous. Disc-shaped starch grains surrounding pyrenoids and in stroma; lipoid reserve absent. Nutrition phototrophic. Trichites distributed in peripheral cytoplasm, more numerous in region of junction of valves. Non-toxic to fish.

Asexual reproduction by fission in the motile state into two daughter-cells of equal or unequal size.

Isolated from sea-water sample taken near Knap Buoy, Plymouth Sound, 
from $8 \mathrm{~m}$ depth on 30 June 1949 (type culture); also from St German's River in tow net sample on 24 June 1957. Type culture (Plymouth no. 18) at the Laboratory of the Marine Biological Association, Plymouth.

Named in honour of Dr Marie V. Lebour on the occasion of her 8oth birthday.

Cellula duabus valvis (materia cellulosa consistentibus) induta, sinistra atque dextra, forma ovali vel sphaerali ut videtur pro superficie utriusque valvae, lenticulari vel fere sphaerali pro conjunctione valvarum; planata extremitate qua oriuntur flagella; longa (IO) I4-I7 (22) $\mu$, lata (9) II I I (20) $\mu$, crassa (5) 6-8 (I8) $\mu$; margine utriusque valvae striolata, latius in majoribus cellulis, striolis $0.5 \mu$ separatis, valvis pro cetero perforatis minutissimis porulis latis $0.20-0.25 \mu$, distributis - ut videtur-in ordinibus regularibus $0.25 \mu$ separatis; valva dextra indentata sinu haud profundo, lato fere $2 \mu$, ad extremitatem qua oriuntur flagella paulum sinistraliter ex norma posito; valva sinistra praedita parvo processu, eminente super sinum valvae dextrae, quem sinum idem replet. Eodem processu perforato a duobus poris ad exitum flagellorum; quibus poris disparibus magnitudine; majore dextro, fere triangulari, minore sinistro, circulari (ut videtur in aspectu sinistrae valvae). Duobus flagellis, altero emergente ex majore poro, undulante circum situm originis suae, longiore $2 \cdot 5-3$ plo quam cellula; altero emergente ex minore poro, longiore $\mathrm{I} \cdot 25-\mathrm{I} \cdot 5 \mathrm{plo}$ quam cellula. Pusulis duabus, altera (quam semper facile potest videre) longa I $5-4 \mu$, in sinistra valva posita, sub superficie, dextraliter prope originem flagellorum, aperiente externe per canaliculam in porum majorem flagelli, altero nonnunquam absente, invisibili ut aperit externe.

\section{Legend to Figs. I-9}

Figs. I-9. Exuviaella mariae-lebouriae n.sp.

(Figs. I-2, × 5000; Figs. 3-9, × 2500)

$c$, chromatophore; $e$, ejecting trichite; $g$, granules in pusule; $l f$, 'longitudinal' flagellum; $m$, mitochondrion?; $n$, nucleus; $n s b$, narrow striated band at margin of valve; $p$, pyrenoid; $p u$, pusule; $s$, starch bodies; $s p$, 2nd pusule; $t$, trichite; $t f$, 'transverse' flagellum; ws $b$, wide striated band at margin of valve.

Fig. I. Left valve view of small individual with two large chromatophores; valve shows large and small flagellar pores and a narrow striated margin.

Fig. 2. Right valve view of large individual with six chromatophores and two pusules, the larger containing granules in Brownian movement; three pyrenoids surrounded by discshaped starch bodies; valve shows wide striated margin and indentation at flagellar pole; the projecting flange of the left valve, bearing the flagellar pores, is seen in the indentation.

Fig. 3. View of flagellar pole showing large and small flagellar pores.

Fig. 4. Empty valves of cell showing flagellar pores on flange of left, and indentation in right, valve.

Fig. 5. Optical section of young compressed cell in side view (junction of valves-left valve on left of diagram) showing connection of pusule to larger flagellar pore.

Fig. 6. Side view of large, nearly sphaeroidal, individual with the wide striated margins to the valves still overlapping.

Fig. 7. Early fission stage with valves not overlapping; the wide striated margins of both valves are clearly visible.

Fig. 8. Late fission stage: daughter-cells still joined by narrow connexion near flagellar pole.

Fig. 9. Newly separated daughter-cell with one valve. 


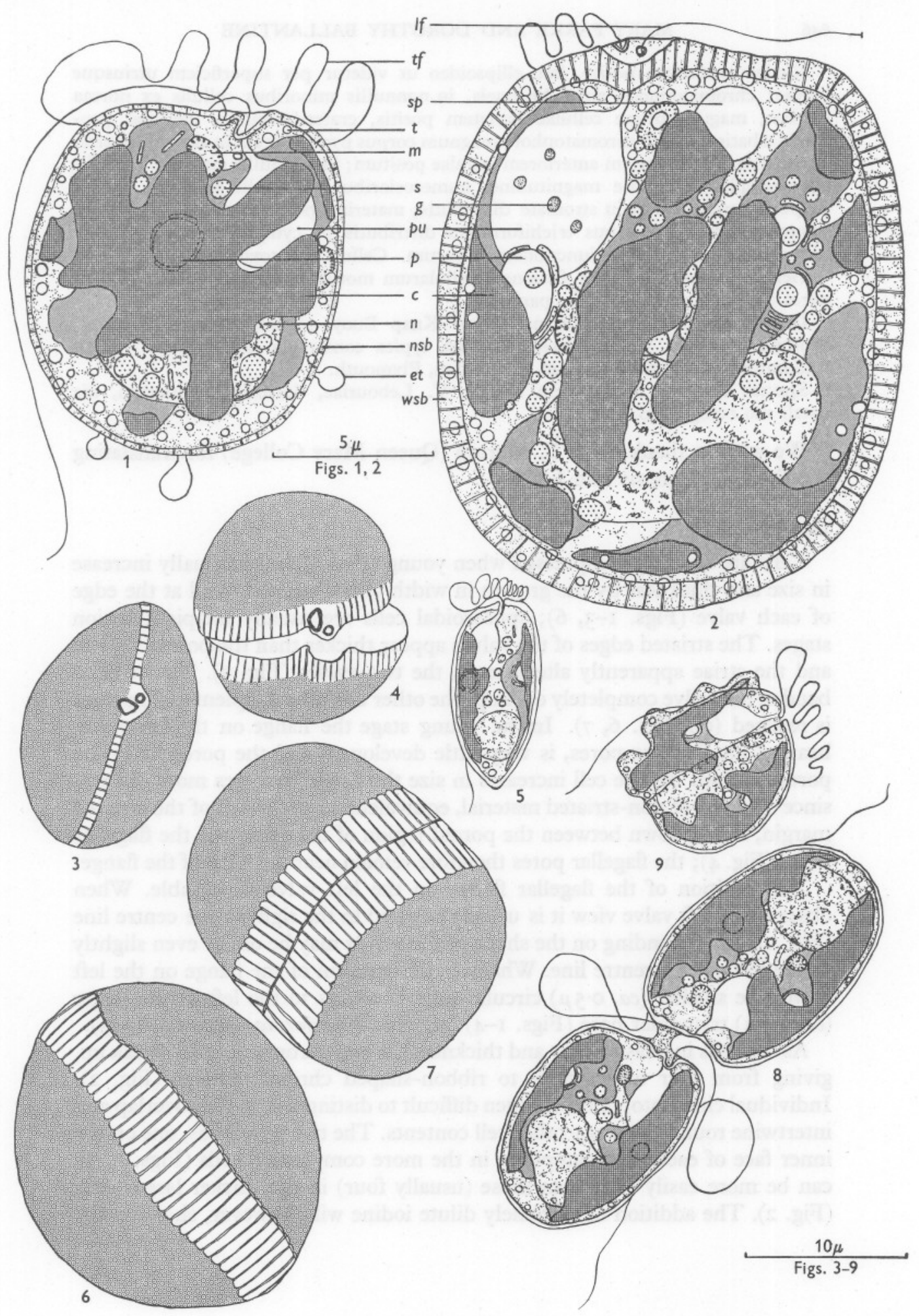

Figs. I-9 
Nucleo posteriore posito, late ellipsoideo ut videtur per superficiem utriusque valvae; chromatophoris aureo-brunneis, in nonnullis minoribus cellulis ex norma duobus, magnis, prope cellulae parietem positis, crateriformibus, margine profunde lobatis, quoque chromatophoro magnum corpus pyrenoideum in aspectu interno continente, versus partem anteriorem cellulae positum; in nonnullis majoribus cellulis chromatophoris minore magnitudine, numerosioribus. Granulis amylosis circum corpora pyrenoidea et in stromate distributis; materia lipoidea absente. Nutritione phototrophica. Corporibus trichiformibus distributis in cytoplasmate superficiali, numerosioribus prope conjunctionem valvarum. Cellula non toxica piscibus.

Generans asexualiter per fissionem cellularum motilium ad duas cellulas filiolas pares vel impares magnitudine pariendas.

Isolata exemplis aquae marinae prope Knap Buoy, regione Plymouth Sound, profund. 8 metr., 30 jun. 1949. Cultura typica conservata (Plym. num. I8) ad Laboratorium Marine Biological Association, Plymouth.

Species dedicata in honorem Mariae V. Lebouriae, doctoris scientiarum, die natali suo octogesimo.

We wish to thank Dr J. E. Morton (Queen Mary College) for translating the English diagnosis into Latin.

\section{Description}

Cells are strongly compressed when young (Fig. 5), but gradually increase in size and thickness by the growth in width of the striated band at the edge of each valve (Figs. I-3, 6); sphaeroidal cells are usually incipient fission stages. The striated edges of the valves appear thicker than the poroid region, and the striae apparently alternate on the two valves (Fig. 7). The striated band of one valve completely overlaps the other until the incipient fission stage is reached (cf. Figs. 6, 7). In the young stage the flange on the left valve, bearing the flagellar pores, is very little developed, and the pores lie in the poroid region. As the cell increases in size the flange becomes more obvious since a region of non-striated material, equivalent to the width of the striated margin, is laid down between the poroid region of the valve and the flagellar pores (Fig. 4); the flagellar pores therefore remain near the edge of the flange.

The position of the flagellar flange on the left valve is variable. When observed in left valve view it is usually situated to the right of the centre line (Fig. I), but depending on the shape of the valves may be on, or even slightly to the left of, the centre line. Whatever the position of the flange on the left valve, the smaller $(c a .0 .5 \mu)$ circular pore is always to the left of the larger $(c a . \mathrm{I} \cdot 5 \mu)$ triangular pore (Figs. I-4) (cf. Porella perforata, Braarud, I945).

As the cells increase in size and thickness the two chromatophores break up, giving from four to six disc- to ribbon-shaped chromatophores (Fig. 2). Individual chromatophores are then difficult to distinguish as they overlap and intertwine round the many other cell contents. The two pyrenoids, one on the inner face of each chromatophore in the more compressed cells (Figs. I, 5), can be more easily seen than those (usually four) in the thicker larger cells (Fig. 2). The addition of extremely dilute iodine will, however, show up the 
pyrenoids more clearly by staining them orange-brown. This dilute iodine also stains blue the very numerous disc-shaped bodies, up to $\mathrm{I} \mu$ in diameter, which we take to be starch (Figs. I, 2 and 5). They surround the pyrenoids and are also freely distributed in the cytoplasm. Both pyrenoids and starch grains are masked by the staining of other cell contents when strong iodine is used. No lipoid reserve has been detected by the use of osmium tetroxide, Sudan black and Sudan IV.

Tests with graphite (cf. Parke, Manton \& Clarke, 1955, p. 582) have given no evidence of phagotrophy. Minute granules (about $0.5 \mu$ ) showing Brownian movement have, however, been found in the large, but not in the small, pusule (Fig. 2). The origin of these granules is unknown. The large pusule (Figs. I, 2 and 5), which opens into the large flagellar pore, can be seen to increase or decrease in size. The contents are immediately exuded as globules through this pore when the undulating flagellum is cast. In life, under the lower powers of the microscope (up to $8 \mathrm{~mm}$ objective), the contents of the pusule appear a very pale pink-fawn, but colourless under higher powers. With cresyl or methylene blue the contents stain pink-violet.

Two ovoid bodies, about $\mathrm{I} \cdot 5 \times \mathrm{I} \mu$ in size, staining with Janus green are possibly mitochondria (Figs. I, 2). As in many Dinophyceae (Chadefaud, 1936, p. 327; Chatton, 1952, p. 313) and Chrysophyceae (Magne, 1954; Parke et al., I955, 1956) this species possesses ejectile organelles (trichites). In the living cell they appear (Figs. I, 2) as refractile spheres about $0.5 \mu$ in diameter, and can exude their contents through the poroids as globules, batons or threads (Fig. I). With cresyl or methylene blue they stain a deep clear blue (cf. Chrysophyceae, Parke et al., 1955, 1956).

During swimming the undulating flagellum ( $\equiv$ transverse flagellum of dinoflagellates possessing a girdle) always moves parallel to, and round, the flagellar pole, only the speed and amplitude of the undulations varying. The position of the so-called longitudinal flagellum varies with the speed of movement of the cell. During rapid swimming it is backwardly directed and vibrates quickly (Fig. Io). Movement of the cell is in an irregular double spiral with many changes of direction. When the cell changes direction the 'longitudinal' flagellum sweeps rapidly forward, the cell stops and the body immediately turns over to lie on the 'longitudinal' flagellum (Figs. IO-I2). The cell then swims away in the new direction. Larger, more sphaeroidal, cells rotate relatively more slowly with a more rolling motion. During slow movement there is no rotation of the body. The cells usually move with the flagellar pole foremost, and with the 'longitudinal' flagellum either directed backwards, and not apparently moving, or sweeping slowly backwards and forwards in a half circle (Fig. 13). Occasionally the cell moves with the non-flagellar pole foremost (Fig. I4) for short periods. Although no stigma can be detected, this species shows a phototactic reaction when exposed to uneven illumination. 
At the peak of growth a culture of this species in Erdschreiber solution will produce about 200,000 cells per ml., which is close to the production of cells ( $160,000 / \mathrm{ml}$.) in a culture of E. baltica Lohmann (Plymouth no. 28).

Cell division takes place in the motile state. As the incipient fission stages gradually increase in thickness, the two valves move apart. At first the wide striated region of the valves is seen as two distinct bands (Fig. 7). After this stage these broad bands are not visible, and there appears to be an area of naked protoplasm between the two valves (Fig. 15). Division of the nucleus then occurs and the two new flagella are formed (Figs. 15, 16). Fission of the body starts at the non-flagellar pole and proceeds until the two daughter-cells are joined by only a narrow connexion near the flagellar pole (Figs. 8, I6-I8).

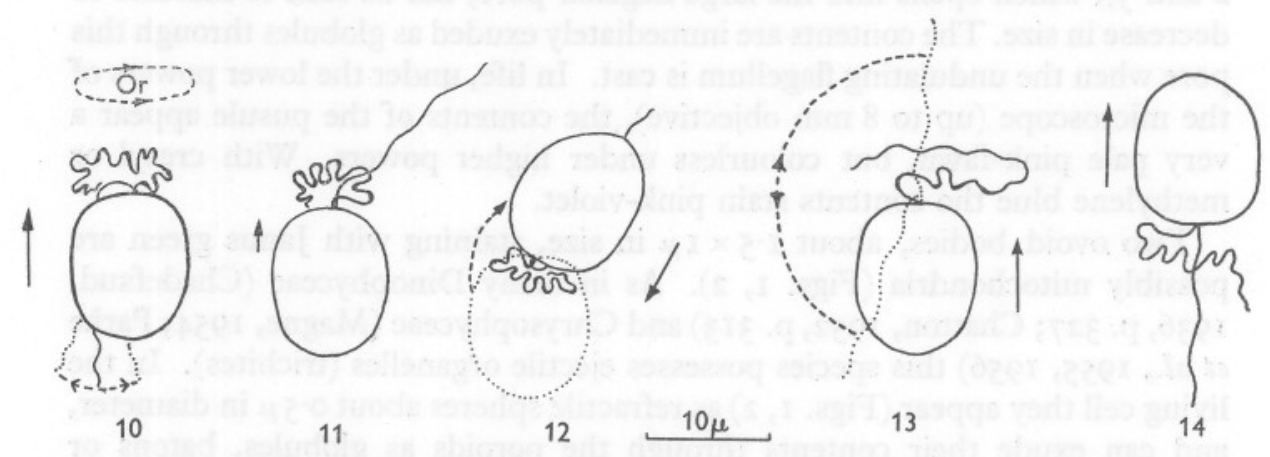

Figs. IO-I4. Exuviaella mariae-lebouriae n.sp. ( $\times$ I250). Cells showing positions of flagella in relation to the body during swimming. Arrows show direction of movement.

Fig. Io. 'Longitudinal' flagellum backwardly directed, vibrating rapidly, as in fast movement.

Fig. Ir. 'Longitudinal' flagellum sweeps forward, cell slows down to change direction.

Fig. 12. Cell-body turns over to lie over the 'longitudinal' flagellum, to complete the change of direction.

Fig. 13. Cell showing action of flagella in slow movement with flagellar pole foremost. 'Transverse' flagellum moves with looser and slower undulations.

Fig. I4. Slow movement with non-flagellar pole foremost.

The two daughter-cells swim joined together for some time, then break apart. Each daughter-cell usually retains one valve and secretes one new one. Small cells with one valve and the remainder of the body showing a lobed outline are seen frequently (Fig. 9). Examination of the valves on late fission stages and newly separated daughter-cells shows that they either lack, or have only very narrow striated margins (Figs. 9, 17); the flange bearing the flagellar pores is also very small (see p. 646). It is thought that the prominent flange and the wide striated margin of the incipient fission stage is either cast or resorbed during fission. If this is the case both daughter-cells will develop new flagellar pores and this is consistent with the evidence obtained from the examination of the valves of young specimens. 
Of the species which show a superficial resemblance to $E$. mariae-lebouriae, $E$. compressa Ostenfeld and E. pusilla Schiller differ in having only one flagellar pore; they can also be distinguished by other characters. E. cordata Ostenfeld appears rather similar but has a depression at the flagellar pole and has thick-walled valves which apparently lack striated margins. E. baltica Lohmann is similar to E. mariae-lebouriae in having two flagellar pores and striated margins to the valves (Woloszynska, I928; also Plymouth Culture no. 28-private communication from Professor T. Braarud and our own observations using a light microscope). E. baltica differs, however, in being smaller and almost spherical, in having smaller flagellar pores, in lacking poroids

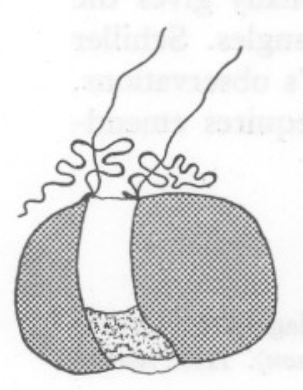

15

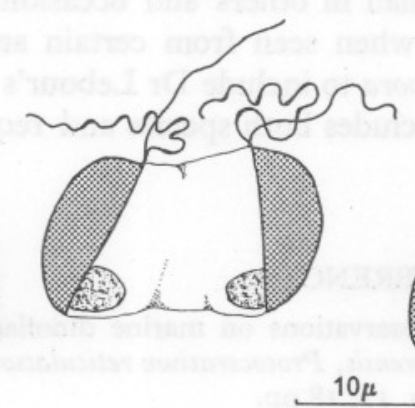

16

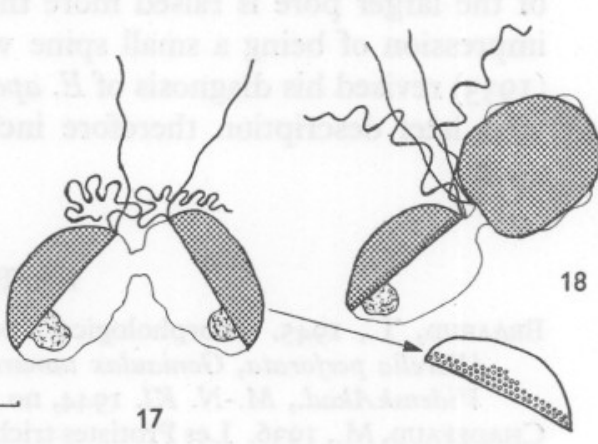

18

Figs. 15-18. Exuviaella mariae-lebouriae n.sp. ( $\times$ 1250). Stages in cell division (see also Figs. 7-9). Valves are indicated by stippled area.

Fig. 15. Early fission stage: the two new flagella are formed and the valves lie apart, leaving an area of naked protoplasm; the broad striated bands at the margins of the valves of incipient fission stages cannot be seen.

Fig. I6. Nucleus has divided, and cell begins to show indentations at poles.

Fig. 17. Later stage of fission, showing position of valves. The inset diagram of one valve shows the poroids extending to the margin of the valve, i.e. striated area is lacking.

Fig. I8. Last stage of fission before daughter-cells break apart; one daughter-cell has twisted round with respect to the other, showing one valve in face view; new valves are not yet formed.

and in the chromatophores being much more distinct and more deeply pigmented, although both species produce starch as a reserve product. E. apora Schiller (I9I8, p. 258) is larger $(30-32 \mu \times 2 \mathrm{I}-26 \mu)$ than E. mariae-lebouriae and the valves lack poroids. In the original diagnosis of $E$. apora there is no mention of the edges of the valves being striated, nor is the number of flagellar pores given. Lebour (1925) placed specimens (I6-22 $\mu$ long) found near Plymouth in Schiller's E. apora, but states: 'It is possible that there are here two separate species...' In these specimens she records the presence of two flagellar pores and striated margins in the older cells. She also records the breaking up of the two chromatophores into small spheres (cf. Martin, I929, p. I0). No poroids in the valves were observed by Dr Lebour, but these can be seen only with critical brightfield illumination and objectives of very high resolution or 
with dark-ground illumination using a $4 \mathrm{~mm}$ objective. We are certain that our material is identical with that described and figured by Dr Lebour and therefore designate her Plymouth specimens, placed by her in $E$. apora Schiller, as E. mariae-lebouriae n.sp. (non E. apora Schiller). Martin (I929) records $E$. apora from New Jersey and states he has 'no hesitation in applying this name in Lebour's sense to our material. Whether it is the same as Schiller's original species is less certain.' In his description Martin mentions that a small spine is sometimes present on the left valve but that it is seen with difficulty and only in certain positions. We have not observed spines on the left valve in our material, but in some specimens the margin of the larger pore is raised more than in others and occasionally gives the impression of being a small spine when seen from certain angles. Schiller (1933) revised his diagnosis of $E$. apora to include Dr Lebour's observations. This later description therefore includes both species and requires emendation.

\section{REFERENCES}

BraARUD, T., 1945. Morphological observations on marine dinoflagellate cultures (Porella perforata, Goniaulax tamarensis, Protoceratium reticulatum). Avh. norske VidenskAkad., M.-N. Kl. I944, no. I1, 18 pp.

Chadefaud, M., 1936. Les Protistes trichocystifères ou Protogastréades. Ann. Protist., Paris, T. 5, pp. 323-4I.

Chatton, E., I952. Classe des Dinoflagelles ou Péridiniens, in Traité de Zoologie, Ed. P. P. Grassé, T. I, Fasc. I, I07I pp. Paris.

Lebour, M. V., I925. The Dinoflagellates of Northern Seas. 250 pp. Plymouth.

MAGNE, F., I954. Les Chrysophycées marines de la Station biologique de Roscoff. Rev. gén. Bot., T. 61, pp. 389-415.

MARTIN, G. W., I929. Dinoflagellates from marine and brackish waters of New Jersey. Stud. nat. Hist. Ia Univ., Vol. 12, no. 9, pp. 1-32.

Parke, M., Manton, I. \& Clarke, B., 1955. Studies on marine flagellates. II. Three new species of Chrysochromulina. F. mar. biol. Ass. U.K., Vol. 34, pp. 579-609.

— - 1956. Studies on marine flagellates. III. Three further species of Chrysochromulina. F. mar. biol. Ass. U.K., Vol. 35, pp. 387-4I4.

SchIller, J., 1918. Über neue Prorocentrum-und Exuviella-Arten aus den Adria. Arch. Protistenk., Bd. 38, pp. 250-62.

- 1933. Dinoflagellatae (Peridineae). Rabenhorst's Kryptogamenflora, Bd. Io, Abt. 3, Teil I.

WoloszynsKa, J., 1928. Dinoflagellatae Polskiego Bałtyku i Błot nad Piaśnicą. Arch. Hydrob. Rybact., T. 3, pp. 153-278. 